\title{
WYMÓG UZYSKANIA TERYTORIALNEGO ROZłOŻENIA GŁOSÓW (POPARCIA) W WYBORACH PREZYDENCKICH
}

\author{
SPATIAL VOTE DISTRIBUTION REQUIREMENT \\ IN PRESIDENTIAL ELECTIONS
}

Krzysztof Trzciński*

\begin{abstract}
ABSTRAKT
Głównym celem tego artykułu jest wyjaśnienie, na czym polega specyfika instytucji wymogu uzyskania terytorialnego rozłożenia głosów w wyborach prezydenckich, istniejącego w: Nigerii od 1979 r., Kenii od 1992 r. i Indonezji od 2001 r., oraz określenie panujących w tych państwach warunków politycznych, które przyczyniły się do jej wprowadzenia i trwania. W końcowej części artykułu, dzięki porównaniu wszystkich trzech kazusów, wskazane zostaną szczegółowe różnice występujące obecnie między nimi. W artykule zostaną również zaprezentowane wnioski dotyczące dotychczasowych doświadczeń związanych $\mathrm{z}$ funkcjonowaniem przedmiotowej instytucji. Pozwolą one wstępnie ocenić, czy uprawnione jest stwierdzenie, że jej zastosowanie wpływa na obniżenie znaczenia konfliktowych zachowań w relacjach między grupami etnicznymi i na budowanie międzyetnicznej akomodacji w wymienionych państwach.
\end{abstract}

\begin{abstract}
The aim of this article is to explain the institution of spatial vote distribution requirement in presidential elections that exists only in three multi-ethnic states: Nigeria (since 1979), Kenya (since 1992), and Indonesia (since 2001). To become a president in any of these states, a candidate who wins majority or plurality of votes in the elections also has to gain their minimal number (e.g. at least 20\%) in more than half of their main administrative units. In the article, the main premises and multi-ethnic political context for applying this institution are identified, as well as differences between all three cases indicated in detail. In the final part, the hitherto experience of employing this institution is evaluated.
\end{abstract}

\footnotetext{
* Polska Akademia Nauk, Instytut Kultur Śródziemnomorskich i Orientalnych.
} 
Słowa kluczowe: wymóg uzyskania terytorialnego rozłożenia głosów, wybory prezydenckie, państwo wieloetniczne, konflikt etniczny
Keywords: vote distribution requirement, presidential elections, multi-ethnic state, ethnic conflict

\section{WSTĘP}

W trzech wieloetnicznych państwach świata: Nigerii, Kenii i Indonezji dla objęcia urzędu prezydenckiego niezbędne jest sprostanie przez kandydata, który zdobywa w wyborach większość głosów (w zależności od przypadku: bezwzględną lub względną), konstytucyjnemu wymogowi uzyskania również terytorialnego ich rozłożenia, a konkretnie otrzymania pewnego minimalnego, procentowo określonego poparcia w znacznej liczbie podstawowych jednostek podziału terytorialnego, na przykład co najmniej $20 \%$ głosów w ponad $50 \%$ prowincji ${ }^{1}$. Ta mało znana instytucja nie istnieje w porządku konstytucyjnym żadnego innego państwa, prócz wymienionych. Wskazany wymóg ma z założenia przybliżać do wygranej tych kandydatów, których poglądy i działania polityczne, zwłaszcza w kwestiach drażliwych w wymiarze interesów poszczególnych grup etnicznych zamieszkujących dane wieloetniczne państwo, mają charakter umiarkowany, a zatem służą międzyetnicznej akomodacji ${ }^{2}$. Szerszym celem jest zachęcanie elit grup etnicznych do tworzenia potencjału dla integracji politycznej w poprzek podziałów etnicznych, osłabiając w ten sposób ich znaczenie w warunkach wieloetniczności. Jak zauważa czołowy badacz i znawca problemów politycznych państw wieloetnicznych, Donald L. Horowitz (1985), wymóg uzyskania terytorialnego rozłożenia głosów w wyborach prezydenckich jest po prostu przykładem rozwiązania pomagającego $\mathrm{w}$ tym, by reprezentowane przez polityków grupy etniczne wykazywały wobec siebie niekonfliktowe lub mniej konfliktowe zachowania.

Głównym celem tego artykułu jest wyjaśnienie, na czym polega specyfika instytucji wymogu uzyskania terytorialnego rozłożenia głosów w wyborach

${ }^{1} \mathrm{~W}$ anglosaskim piśmiennictwie naukowym nie istnieje jeden termin określający instytucję, której poświęcony jest ten artykuł. W użyciu są natomiast następujące pojęcia: spatial distribution requirement, presidential distribution requirement, vote distribution requirement, regional distribution requirement, distribution requirement in presidential elections i electoral distribution requirement. Żadne $\mathrm{z}$ nich nie jest jednak tak dokładne jak proponowana w tytule wersja polska.

${ }^{2}$ Pod tym coraz popularniejszym - a stosowanym w polskim piśmiennictwie politologicznym w różnych znaczeniach - pojęciem rozumiane jest w tym artykule „wzajemne przystosowanie się” i „osiąganie kompromisu” w relacjach członków elit politycznych. 
prezydenckich, istniejącego w: Nigerii od 1979 r., Kenii od 1992 r. i Indonezji od 2001 r. oraz określenie panujących w tych państwach warunków politycznych, które przyczyniły się do jej wprowadzenia i trwania. W końcowej części artykułu, dzięki porównaniu wszystkich trzech kazusów, wskazane zostaną szczegółowe różnice występujące obecnie między nimi. W artykule zostaną również zaprezentowane wnioski dotyczące dotychczasowych doświadczeń związanych $z$ funkcjonowaniem przedmiotowej instytucji. Pozwolą one wstępnie ocenić, czy uprawnione jest stwierdzenie, że jej zastosowanie wpływa na obniżenie znaczenia konfliktowych zachowań w relacjach między grupami etnicznymi i na budowanie międzyetnicznej akomodacji w wymienionych państwach.

\section{PODSTAWOWE POJĘCIA}

Nigeria, Kenia i Indonezja należą do ważnych państw rozwijających się. Nigeria i Indonezja mają dużą liczbę ludności (zajmują obecnie kolejno 4. i 7. miejsce wśród państw świata o największej populacji) i posiadają bogate złoża surowców energetycznych (ropy naftowej i gazu ziemnego). Indonezja i Kenia należą do najatrakcyjniejszych państw świata pod względem posiadanych walorów przyrodniczych i kulturowych, dzięki czemu stanowią cel licznych podróży zagranicznych turystów. Wszystkie trzy państwa zmagają się z problemem ekstremizmu islamskiego. Podstawową cechą ich społeczeństw jest wieloetniczność. W relacjach między zamieszkującymi je grupami etnicznymi przynajmniej okresowo dochodzi do konfliktów i przemocy. W konsekwencji społeczeństwa Nigerii, Kenii i Indonezji niejednokrotnie w literaturze przedmiotu określane są mianem głęboko podzielonych. Dla jasności dalszej analizy należy zdefiniować użyte tu pojęcia.

Państwo wieloetniczne to, jak sama nazwa wskazuje, państwo tworzone przez członków wielu grup etnicznych. Arend Lijphart (1995, s. 853) definiuje grupę etniczną jako „grupę ludzi, którzy postrzegają siebie jako odrębną wspólnotę kulturową, których często łączą wspólne: język, religia, pokrewieństwo i/lub cechy fizyczne (takie jak na przykład kolor skóry) i którzy mają skłonność do żywienia negatywnych oraz wrogich uczuć wobec członków innych grup etnicznych". W opinii Timothy'ego D. Siska (1996, s. 119) pojęcie "grupa etniczna” oznacza grupę zorganizowaną na fundamencie wspólnej tożsamości, czy też charakteryzującej jej członków „wspólnej percepcji pochodzenia”, włączając w to grupę zorganizowaną na bazie wspólnej „religii, kultury, języka, rasy i kasty”. Sisk (1996, 
s. 3) tłumaczy, że społeczeństwo głęboko podzielone (deeply divided society) to takie wielosegmentowe (najczęściej wieloetniczne, a niekiedy wieloreligijne lub wielowyznaniowe) społeczeństwo, w którym przynajmniej od czasu do czasu dochodziło lub dochodzi - na podłożu istniejących w nim międzysegmentowych różnic - do krwawych walk, a nawet „wymuszanej asymilacji, 'czystek etnicznych' lub przymusowych wypędzeń oraz ludobójstwa”. Tego rodzaju zjawiska korespondują z pojęciami „konflikt etniczny” i „przemoc etniczna”.

Errol A. Henderson (1999) określa konflikt etniczny lub międzyetniczny (ethnic conflict, interethnic conflict) jako spory między rywalizującymi ze sobą grupami, które identyfikują siebie głównie w oparciu o kryteria etniczne (tj. związane z takimi wspólnymi cechami, jak: etniczność, język, religia i rasa), oraz które wysuwają grupowe roszczenia do jakichś zasobów na podstawie swoich praw grupowych. Stuart J. Kaufman (2011), przypominając, że większość państw świata jest etnicznie zróżnicowana, a stosunki między zamieszkującymi je grupami etnicznymi zwykle generują jakieś konflikty, wskazuje, że konkretny konflikt można nazwać etnicznym wówczas, gdy jego strony mogą być wyróżnione przede wszystkim z powodu ich odmiennej etniczności (pojmowanej w znaczeniu tożsamości etnicznej), zaś podstawą zaangażowania ludzi w konflikt jest ich grupowa przynależność, a nie jakiś inny czynnik. Niemniej jednak, każda lub niektóre ze stron konfliktu mogą równie dobrze być koalicjami dwóch lub więcej grup etnicznych.

Definiując konflikt etniczny w taki sposób, Kaufman (2011) zdaje sobie zarazem sprawę z faktu, że zasadność stosowania pojęcia „konflikt etniczny” jest podważana i są tego istotne podstawy. Mianowicie część badaczy, określanych mianem instrumentalistów, uważa, że tożsamości etniczne w niejednym przypadku są po prostu wykorzystywane przez klasę polityczną lub jej część w rywalizacji, zwłaszcza o dostęp do dóbr ekonomicznych. W konsekwencji grupy etniczne nie wchodzą ze sobą w konflikt jedynie z powodu swej odmienności. Samo współistnienie w danym państwie różnych grup etnicznych nie może zatem być przyczyną konfliktu jako takiego, a tożsamości etniczne nie mogą generować konfliktów etnicznych, gdyż takowe nie istnieją.

Kaufman (2011) zauważa jednocześnie, że z kolei dla wielu innych badaczy pojęcie konfliktu etnicznego jest po prostu dalece nieprecyzyjne. Stan ten skutkuje często brakiem zgody co do tego, czy dany konflikt można nazwać etnicznym. Niemniej jednak stoi on zarazem na stanowisku, że o konflikcie etnicznym można już mówić w sytuacji, gdy dochodzi do rywalizacji jakichś 
interesów kojarzonych z konkretnymi grupami etnicznymi i wyróżnia najważniejsze $\mathrm{z}$ tych interesów: językowe, religijne i ekonomiczne.

Dla konfliktu etnicznego niejednokrotnie symptomatyczna jest również sytuacja, gdy tożsamości etniczne generują kolejne spory, które wychodzą poza którąś $\mathrm{z}$ wymienionych, podstawowych różnic interesów, na przykład, gdy niezgoda w jakiejś bardzo istotnej sprawie, choćby redystrybucji środków budżetowych między regiony państwa zamieszkane przez konkretne grupy etniczne, powoduje powstawanie napięć w innych płaszczyznach stosunków międzyetnicznych, zwłaszcza tam, gdzie napięcia te dotychczas się nie ujawniały. Ponadto niejednokrotnie to nie konkretne interesy prowadzą do rozwoju jakiegoś konfliktu etnicznego, lecz sprawy z pozoru o znaczeniu symbolicznym, jak np. chęć używania własnej flagi, która może mieć dla danej grupy istotny sens z perspektywy poczucia własnej wartości jej członków (Kaufman, 2011).

Komplikując problematykę terminologiczną dotyczącą międzyetnicznej konfrontacji, należy również zauważyć częste używanie w piśmiennictwie naukowym pojęcia „przemoc etniczna” (ethnic violence ${ }^{3}$ ). Termin ten może być uznany za szerszy od przedstawionego wcześniej rozumienia pojęcia konfliktu etnicznego w sensie takiego wybuchu nieporozumień między członkami różnych grup etnicznych, które ex definitione zawierają w sobie użycie przemocy. $\mathrm{Z}$ drugiej jednak strony, przemoc etniczna może mieć charakter nagły, krótkotrwały, pozbawiony organizacji i wówczas ma węższe znaczenie od terminu konflikt etniczny, który zdaje się zawierać w sobie element przewlekłości czy też długotrwałości. Postrzegając tę kwestię z jeszcze innej perspektywy, można uznać przemoc etniczną po prostu za wymiar konfliktu etnicznego. Jak można wnioskować, u podłoża przemocy etnicznej powinna leżeć międzyetniczna nienawiść bądź, ujmując rzecz bardziej oględnie, jakieś animozje, niechęci czy uprzedzenia. Wrogości w stosunkach między członkami danych grup etnicznych, bazującej na przykład na jakichś uprzedzeniach etnicznych, często jednak nie sposób odróżnić od antagonizmów mających podstawę w innych przesłankach, na przykład ideologicznych, ekonomicznych czy politycznych.

${ }^{3}$ Pojęcie to niekiedy używane jest $\mathrm{w}$ anglosaskim piśmiennictwie naukowym wraz z terminem sectarian violence, który można tłumaczyć jako przemoc na tle religijnym, czy też przemoc zachodzącą w stosunkach między członkami odmiennych grup religijnych lub wyznaniowych. 


\section{KONTEKST WPROWADZENIA WYMOGU UZYSKANIA TERYTORIALNEGO ROZŁOŻENIA GŁOSÓW W WYBORACH PREZYDENCKICH W NIGERII, KENII I INDONEZJI}

Przed wyjaśnieniem, na czym polega instytucja wymogu uzyskania terytorialnego rozłożenia głosów w wyborach prezydenckich, należy zidentyfikować wewnętrzne warunki polityczne panujące kolejno w Nigerii, Kenii i Indonezji, które przyczyniły się do jej implementacji i funkcjonowania.

\section{PRZYPADEK NIGERII}

Nigeria jest obecnie najludniejszym państwem Afryki i siódmym największym państwem świata pod względem liczby mieszkańców, która, jak się szacuje, na początku 2015 r. osiągnęła $181 \mathrm{mln}$ (Geohive, 2015). Jest to typowe państwo wieloetniczne i zarazem wielokulturowe. Na liczącym blisko 924 tys. $\mathrm{km}^{2}$ terytorium Nigerii w użyciu są aż 522 lokalne języki (Ethnologue - Languages of the World, 2015b), choć język urzędowy jest jeden - angielski. Państwo to zamieszkują członkowie ok. 250 grup etnicznych (Encyclopedia of the Nations, 2015b), wśród których największe to Hausa-Fulani (mająca ok. 29\% udział w populacji Nigerii), Joruba (ok. 21\%), Igbo (Ibo, ok. 18\%) i Ijaw (ok. 10\%; Index Mundi, 2014c). To samo źródło szacuje, że ok. 50\% mieszkańców Nigerii to muzułmanie, ok. 40\% to chrześcijanie, a ok. $10 \%$ to wyznawcy wierzeń rodzimych.

Współcześnie najpoważniejszym konfliktem w Nigerii jest rewolta ekstremistycznej, muzułmańskiej organizacji Boko Haram (Jama’atu Ahlis Sunna Lidda'Awati Wal-Jihad), która wymierzona jest we władze nigeryjskie, chrześcijan oraz w tych wyznawców islamu, którzy tolerują zachodnie wpływy przede wszystkim w oświacie, nauce, administracji i systemie politycznym. Choć ten toczący się głównie w północno-wschodniej części Nigerii konflikt z pewnością ma pewne cechy konfliktu religijnego, trudno dopatrzyć się w nim szerszego kontekstu stricte etnicznego. Ten zauważalny jest do pewnego stopnia w innym ważnym konflikcie, ostatnio o niskiej intensywności, który od początku lat dziewięćdziesiątych XX wieku toczy się w Delcie Nigru. Zgrupowani w rozmaitych organizacjach zbrojnych członkowie zwłaszcza dwóch grup etnicznych zamieszkujących ten obszar, Ijaw i Ogoni, przeciwstawiają się, jak to ujmują, ich ekonomicznej eksploatacji przez członków grup etnicznych, mieszkających na północ od Delty, którzy mają kluczowy wpływ na skład i działania rządu Nigerii. Konflikt ten 
ma jednak specyficzny charakter, gdyż bezpośrednim celem ataków rebeliantów z Delty Nigru są najczęściej nie tyle siły państwa nigeryjskiego, co pracownicy i instalacje zachodnich koncernów naftowych, które eksploatują surowce Delty. Rebelianci, uderzając w przemysł naftowy, zmniejszają jednak wpływy budżetowe Nigerii. Jak bowiem wyjaśnia znany nigeryjski politolog Rotimi Suberu (2006) aż ok. 80\% przychodów państwa nigeryjskiego pochodzi z rozmaitych podatków i opłat uiszczanych przez podmioty wydobywające ropę naftową i gaz ziemny w Delcie Nigru. Co najmniej 13\% tych dochodów musi zostać zwrócone do kilku południowych stanów Nigerii, w których bogactwa te są wydobywane. Biorąc jednak pod uwagę bardzo wysoki poziom korupcji w Nigerii, zwrot części środków do stanów w Delcie Nigru wcale nie musi oznaczać ich racjonalnego wykorzystania dla dobra tamtejszej ludności. Ogólnie rzecz ujmując, stany zamieszkane przez największe grupy etniczne zyskują nieproporcjonalnie dużo w stosunku do kilku bogatych w surowce stanów położnych w Delcie Nigru, które zamieszkane są przez mniejsze grupy etniczne.

Do przedstawionych wcześniej definicji pojęcia konfliktu etnicznego zapewne najbardziej w przypadku Nigerii pasuje jednak historyczny już kazus tzw. wojny biafrańskiej (zwanej też nigeryjską wojną domową, która toczyła się w latach 1967-1970), a zwłaszcza wydarzeń, które ją poprzedziły. Wojna wybuchła w siedem lat po uzyskaniu przez Nigerię niepodległości w granicach ustanowionych jeszcze w czasach kolonialnych przez Europejczyków, którzy nie respektowali podziałów etnicznych, językowych i religijnych. Nowo ustanowione wieloetniczne i wielokulturowe państwo niemal natychmiast stało się areną międzysegmentowych napięć, podsycanych przez elity polityczne występujące jako reprezentanci interesów poszczególnych segmentów. U podłoża tych napięć leżały m.in.: wyraźne różnice kulturowe (dzielące Nigeryjczyków $\mathrm{z}$ - w przeważającym stopniu muzułmańskiej - północy i głównie chrześcijańskiej pozostałej części państwa); kwestia podziału przychodów budżetowych (w znacznym stopniu pochodzących z eksploatacji ropy naftowej w Delcie Nigru); jak również problemy związane $\mathrm{z}$ charakteryzującymi główne grupy etniczne odmiennymi tradycjami politycznymi i trudnościami w ich pogodzeniu w sytuacji konieczności wspólnego rządzenia niepodległym państwem.

Bezpośredniej genezy wojny biafrańskiej można się doszukiwać w wojskowym zamachu stanu ze stycznia 1966 r., który postrzegany był zwłaszcza przez część elit Hausa-Fulanich i Jorubów jako przygotowany i przeprowadzony głównie przez oficerów wywodzących się z grupy etnicznej Igbo. Zamach miał być próbą zapobieżenia dezintegracji terytorialnej Nigerii, zwłaszcza w obliczu 
tendencji separatystycznych występujących wśród części elit Północy. W konsekwencji do niej ostatecznie doprowadził, choć na wschodzie tego państwa. Mimo że pucz się nie powiódł, w jego wyniku zginęła znaczna część czołowych nigeryjskich polityków, funkcjonariuszy państwowych, a także wysokiej rangi oficerów wywodzących się z ówczesnych regionów: Północnego (zdominowanego przez Hausa-Fulanich) i Zachodniego (zdominowanego przez Jorubów). Zamachowcy oszczędzili natomiast członków nigeryjskich elit politycznych i wojskowych, którzy pochodzili z grupy Igbo, dominującej w obfitującym w ropę naftową Regionie Wschodnim, na obszarze którego leżała Delta Nigru. W następstwie skomplikowanej sytuacji politycznej w Nigerii po zamachu stanu z 1966 r. i prześladowań Igbów, zwłaszcza przez Hausa-Fulanich, Igbowie ogłosili secesję kontrolowanego przez siebie Regionu Wschodniego i utworzenie na jego obszarze niepodległej Republiki Biafry ${ }^{4}$. Mediacja międzynarodowa nie doprowadziła do zmniejszenia napięć między stronami narastającego konfliktu. W lipcu 1967 r. Biafra została zaatakowana przez siły federalne. Tak wyglądała geneza nigeryjskiej wojny domowej, w której zginęła dokładnie nieustalona liczba ofiar, szacowana jednak w większości źródeł na ponad $1 \mathrm{mln}$. Po zakończeniu trwającego blisko trzy lata konfliktu Igbowie byli w rozmaity sposób dyskryminowani przez władze Nigerii (Obi-Ani, 2005), w której rządziła junta wojskowa.

Jak wskazuje Horowitz (2014, s. 10), po 1978 r., gdy armia oddała władzę cywilom, w wieloetnicznym społeczeństwie, zmęczonym wojną biafrańską i latami rządów wojskowej dyktatury, panował „strach przed odnowieniem konfliktu, przy czym żadna grupa nie wiedziała, która z nich stanie się ofiarą nowych represji”. Wówczas do nowej nigeryjskiej ustawy zasadniczej (Konstytucji tzw. Drugiej Republiki Nigerii z 1 października 1979 r.) zostało wprowadzone postanowienie o konieczności spełnienia niezbędnego dla objęcia urzędu prezydenckiego wymogu uzyskania w wyborach terytorialnego rozłożenia głosów.

\section{PRZYPADEK KENII}

Jak się szacuje, na początku 2015 r. Kenia miała ponad 46 mln mieszkańców (Geohive, 2015). Tak jak Nigeria, Kenia również jest typowym państwem wieloetnicznym i wielokulturowym. Na liczącym blisko 583 tys. $\mathrm{km}^{2}$ terytorium

\footnotetext{
${ }^{4}$ Republika Biafry ze stolicą w Enugu uzyskała później uznanie międzynarodowe jedynie pięciu państw i formalnie istniała do $1970 \mathrm{r}$.
} 
Kenii w użyciu jest 67 lokalnych języków (Ethnologue - Languages of the World, 2015a), choć języki urzędowe są dwa - angielski i swahili. Kenię zamieszkują członkowie ponad 70 grup etnicznych (East Africa Living Encyclopedia, 2015), wśród których pięć ma ponad dziesięcioprocentowy udział w populacji: Kikuju (ok. 22\% mieszkańców Kenii), Luhja (ok. 14\%), Luo (ok. 13\%), Kalendżin (ok. 12\%) i Kamba (ok. 11\%; Encyclopedia of the Nations, 2015a). Według danych z 2009 r. ponad 82\% mieszkańców Kenii to chrześcijanie (głównie protestanci), a ok. 11\% to muzułmanie; wyznawców wierzeń rodzimych jest w Kenii ok. 1,6\% (Index Mundi, 2014b).

Kenijski przypadek wprowadzenia wymogu uzyskania terytorialnego rozłożenia głosów w wyborach prezydenckich jest odmienny od nigeryjskiego. Zasadnicza różnica polega na tym, że przed wprowadzeniem w 1992 r. przedmiotowego wymogu w Kenii nie występowały konflikty czy przemoc etniczna na znaczną skalę. Mimo że oficjalnie wprowadzenie do ustawy zasadniczej przedmiotowego wymogu miało związek z wieloetnicznym charakterem państwa i koniecznością zabiegania polityków kandydujących na urząd prezydenta o głosy wyborcze członków różnych grup etnicznych, to de facto wiązało się raczej z chęcią utrzymania się u władzy wieloletniego dyktatora, Daniela arapa Moiego, prezydenta Kenii od 1978 r., który w dobie demokratyzacji musiał stawić czoło rozmaitym kontrkandydatom do urzędu prezydenckiego. Wymóg uzyskania w wyborach prezydenckich terytorialnego rozłożenia głosów pomyślany był zatem po to, by zwiększyć szanse Moiego, dysponującego zorganizowanym przez lata rządów rozbudowanym aparatem partyjnym na terenie całej Kenii i zmniejszyć szanse tych, którzy na pomoc takiego aparatu liczyć nie mogli. Było to o tyle istotne, że faworytowi wyborów prezydenckich, który spełnił przedmiotowy wymóg do ich wygrania, potrzebne było wówczas jedynie uzyskanie względnej większości oddanych głosów.

Wymóg uzyskania w wyborach prezydenckich terytorialnego rozłożenia głosów w rzeczywistości mógł przynajmniej po części odegrać wskazaną rolę, gdyż Moi w pierwszej turze wygrał wybory w latach 1992 i 1997, uzyskując względną większość głosów. Opozycja wskazywała, że wybory te były fałszowane. Oskarżenia te dotyczyły również wyborów prezydenckich w latach 2002 i 2007 (Moi nie brał w nich już udziału), które wygrał Mwai Kibaki, wcześniej główny oponent Moiego.

Dopiero w kontekście wyborów prezydenckich w Kenii w 2007 r. wybuchł poważny konflikt etniczny, zwany często Kryzysem Kenijskim, który toczył się do 2008 r. Kryzys Kenijski rozgrywał się głównie między członkami grup etnicznych 
Kalendżiów i Luo, a z drugiej strony - Kikujów. U jego podstaw leżał zarówno poważny spór na tle własności ziemi, jak i kwestionowanie wyników wyborów prezydenckich z $2007 \mathrm{r}$. Konflikt pochłonął ponad tysiąc ofiar, a ponad 3 tysiące Kenijczyków zostało w jego wyniku uchodźcami wewnętrznymi (Szupejko, 2012). W 2010 r. w Kenii została promulgowana nowa ustawa zasadnicza, która utrzymała wymóg uzyskania terytorialnego rozłożenia głosów w wyborach prezydenckich. Konstytucję tę wprowadzono w wyniku porozumienia wieńczącego Kryzys Kenijski, a osiągniętego między elitami politycznymi głównych kenijskich grup etnicznych.

\section{PRZYPADEK INDONEZJI}

Indonezja zajmuje obecnie czwarte miejsce wśród najludniejszych państw świata - w 2014 r. miała ok. 254 mln mieszkańców (Index Mundi, 2014a). Jest państwem o bardzo dużej powierzchni, niemal $2 \mathrm{mln} \mathrm{km}^{2}$, rozległym terytorialnie (jej rozciągłość równoleżnikowa wynosi ponad 5 tys. km) i składa się z ponad 17 tys. wysp, z których ponad 6 tys. jest zamieszkałych. Na wielu wyspach Indonezji powstały unikalne kultury. Jej społeczeństwo jest silnie podzielone pod względem etnicznym, a w mniejszym stopniu również i religijnym. Zgodnie z danymi z 2010 r. największą grupą etniczną w Indonezji są Jawajczycy (nieco ponad 40\% ogółu mieszkańców), a znaczący udział w jej społeczeństwie mają również Sundajczycy (ok. 15,5\%), Malajowie (ok. 3,7\%), Batakowie (ok. 3,6\%) i Madurowie (ok. 3\%; Index Mundi, 2014a). Udział członków każdej z kilkuset pozostałych, rodzimych grup etnicznych ${ }^{5}$ w społeczeństwie Indonezji wynosi w każdym przypadku poniżej 3\%. Wśród ludności napływowej najwięcej w Indonezji mieszka Chińczyków (ok. 1,2\% populacji). Według danych z 2010 r. zdecydowana większość Indonezyjczyków, bo ok. 87\%, to muzułmanie, w przeważającej części sunnici. Chrześcijan jest w Indonezji niecałe 10\% (protestanci i katolicy), a wyznawców hinduizmu - ok. 1, 7\% (Index Mundi, 2014a; Macdonald, 2013).

Wprowadzenie w Indonezji na fali demokratyzacji na przełomie XX i XXI wieku wymogu uzyskania terytorialnego rozłożenia głosów w wyborach prezydenckich determinowane było dwoma podstawowymi czynnikami. Po pierwsze,

${ }^{5}$ Według niektórych badaczy w Indonezji jest ponad tysiąc grup etnicznych i plemion (Macdonald, 2013). 
mniejsze grupy etniczne bały się wykorzystywania przez Jawajczyków ich przewagi politycznej i ekonomicznej w celu narzucania im swej woli. Jak wskazuje Horowitz (2013), przy zastosowaniu niektórych systemów wyborczych mieszkańcy wyspy Jawa bądź też tylko etniczni Jawajczycy mogliby mieć wystarczającą siłę głosów, by samodzielnie wybierać prezydenta Indonezji. Bojaźń członków indonezyjskich mniejszości etnicznych przed Jawajczykami podsycana jest zarówno ich silną dominacją, zwłaszcza w życiu politycznym Indonezji w okresie rządów autorytarnych ${ }^{6}$, jak i faktem, że wielu z nich migruje z przeludnionej Jawy na inne wyspy tego państwa. To ostanie zjawisko niejednokrotnie spotyka się z niezadowoleniem lokalnej ludności, obawiającej się nadmiernego wpływu imigrantów na swoje życie. Majoryzacji Jawajczyków, z których przeważająca większość jest muzułmanami, obawiają się szczególnie chrześcijanie, zwłaszcza na Molukach, na niektórych obszarach Celebesu, a także w indonezyjskiej części Nowej Gwinei.

Po drugie, część elit politycznych Indonezji, zwłaszcza jawajskich, obawiało się po rozpoczęciu w 1998 r. przemian demokratycznych ${ }^{7}$ dezintegracji terytorialnej tego państwa, a konkretnie secesji niektórych jego regionów. Symptomem tego problemu było oficjalne uzyskanie niepodległości przez Timor Wschodni w 2002 r. Tendencje separatystyczne w niepodległej Indonezji były i nadal są (w mniejszym stopniu) żywe w północnej części Sumatry, w prowincji Aceh (mimo podpisania porozumienia pokojowego między separatystami a władzami indonezyjskimi w 2005 r.) oraz w indonezyjskiej części Nowej Gwinei, w prowincjach Papua i Papua Zachodnia (McGibbon, 2004). Aceh i prowincje Papui posiadają obecnie autonomię. Tendencje separatystyczne występują nadto na wieloetnicznych Molukach we wschodniej części Archipelagu Malajskiego, w prowincjach Moluki i Moluki Północne, gdzie część grup etnicznych wyznaje islam, a część chrześcijaństwo ${ }^{8}$.

${ }^{6}$ Horowitz (2013, s. 59) zauważa, że za czasów rządów Suharto Jawajczycy nie tylko mieli kluczowy wpływ na władzę centralną, ale poprzez emerytowanych oficerów armii indonezyjskiej tworzyli „trzon kontroli politycznej” poza Jawą, na tzw. zewnętrznych wyspach Indonezji.

7 Początkiem tych przemian było ustąpienie w 1998 r. na fali protestów społecznych prezydenta Suharto (rządzącego nieprzerwanie od 1967 r.) i pierwsze wielopartyjne wybory parlamentarne w 1999 r.

${ }^{8}$ W latach 1999-2002 Moluki były areną krwawego konfliktu (toczącego się głównie na wyspach: Ambon i Halmahera) między wyznawcami obu religii i zarazem różnymi grupami etnicznymi oraz interweniującą armią i policją indonezyjską, których członkowie okresowo zasilali szeregi i wspierali obie strony konfliktu. 
Umiarkowane tendencje separatystyczne lub dążenia do uzyskania autonomii okresowo pojawiają się również w środkowo-wschodniej części Sumatry, w regionie Riau (obecnie dwie prowincje: Riau i Archipelag Riau), obfitującym w bogactwa naturalne, a zamieszkałym w znacznym stopniu przez Malajów, Bataków i Chińczyków. W prowincji Borneo Środkowe okresowo wybuchają konflikty między rodzimymi Dajakami i Malajami a migrantami z wyspy Madura, Madurami; zaś w prowincji Borneo Zachodnie - między Malajami i Dajakami z jednej strony, a Madurami z drugiej.

Jak podkreśla Horowitz (2013), koncepcja wymogu uzyskania terytorialnego rozłożenia głosów w wyborach prezydenckich została, po długich dyskusjach, zapożyczona przez indonezyjskich polityków i konstytucjonalistów w 2001 r. z Nigerii ${ }^{9}$. Horowitz uważa, że indonezyjskiej klasie politycznej, opowiadającej się za wprowadzeniem w wyborach prezydenckich tego wymogu, przyświecała obawa przed powstaniem sytuacji, w której jakiś segment, na przykład etniczny, „zagarnąłby prezydenturę dla siebie” i przyczynił się do „polaryzacji państwa” (Horowitz, 2013, s. 115). Oczywiste jest jednak, że wymóg uzyskania terytorialnego rozłożenia głosów miał zarazem ułatwiać międzyetniczną akomodację.

\section{ISTOTA INSTYTUCJI WYMOGU UZYSKANIA TERYTORIALNEGO ROZŁOŻENIA GŁOSÓW W WYBORACH PREZYDENCKICH W NIGERII, KENII I INDONEZJI}

W tej części artykułu zostaną wyjaśnione specyficzne cechy wymogu uzyskania terytorialnego rozłożenia głosów w wyborach prezydenckich w Nigerii, Kenii i Indonezji. W przypadkach Nigerii i Kenii zostaną wskazane odmienności istniejące w rozwiązaniach dotyczących przedmiotowego wymogu w obecnych konstytucjach oraz we wcześniej obowiązujących ustawach zasadniczych.

9 I wprowadzona do Konstytucji Republiki Indonezji z 18 sierpnia 1945 r. w ramach Trzeciej Poprawki z 9 listopada $2001 \mathrm{r}$. 


\section{Obecne rozwiązania nigeryjskie}

W Republice Federalnej Nigerii, zgodnie z Konstytucją tzw. Czwartej Republiki z 29 maja 1999 r., prezydent jest zarówno głową państwa, jak i kieruje rządem (art. 130 [2]). Wybierany jest w wyborach powszechnych na kadencję czteroletnią (art. 135 [2]). Ta sama osoba nie może pełnić urzędu prezydenckiego więcej niż dwa razy (art. 137 [1] [b]). Obywatel Nigerii może ubiegać się o urząd prezydenta jedynie wówczas, gdy jest członkiem którejś z działających w tym państwie partii politycznych, a jego kandydatura jest przez tę partię finansowana (art. 131 [c]). Wymóg uzyskania terytorialnego rozłożenia głosów w wyborach prezydenckich w Nigerii ma odniesienie do stanów jako podstawowych jednostek podziału terytorialnego (federacja Nigerii składa się obecnie z 36 stanów) i do Federalnego Terytorium Stołecznego (FTS), Abudży (art. 3 [1] i [4]).

Zgodnie z Konstytucją z 1999 r. przedmiotowy wymóg w pierwszej turze wyborów prezydenckich w Nigerii ma zastosowanie do trzech różnych przypadków, które mogą zaistnieć w zależności od liczby osób kandydujących na urząd prezydenta. Po pierwsze, w mało prawdopodobnym przypadku, gdyby w wyborach prezydenckich został wysunięty tylko jeden kandydat, dla objęcia urzędu prezydenckiego musiałby on uzyskać więcej głosów pozytywnych (YES) niż głosów negatywnych $(N O)$ oraz nie mniej niż jedną czwartą głosów pozytywnych oddanych w każdym z co najmniej dwóch trzecich ogółu stanów federacji (liczonych wraz z FTS; art. 133 [a] i [b]).

Po drugie, w przypadku gdyby w wyborach prezydenckich zostało wysuniętych dwóch kandydatów, prezydentem wybrany zostałby ten spośród nich, który zdobyłby więcej niż połowę wszystkich oddanych głosów oraz nie mniej niż jedną czwartą głosów oddanych w każdym z co najmniej dwóch trzecich ogółu stanów federacji (liczonych wraz z FTS; art. 134 [1] [a] i [b]).

Po trzecie, w najbardziej prawdopodobnej i typowej dla Nigerii sytuacji, gdy w wyborach prezydenckich bierze udział więcej niż dwóch kandydatów, urząd prezydenta powinien objąć ten spośród nich, który otrzymał największą liczbę oddanych głosów oraz nie mniej niż jedną czwartą głosów oddanych w każdym z co najmniej dwóch trzecich ogółu stanów federacji (liczonych wraz z FTS; art. $134[2][a]$ i [b]).

Jeśli żaden z kandydatów nie spełni wymogów koniecznych do objęcia urzędu głowy państwa, wówczas Niezależna Państwowa Komisja Wyborcza (NPKN) powinna w przeciągu 7 dni od ogłoszenia wyników tych wyborów ustalić termin ich drugiej tury (art. 134 [4]). Mogą w niej wziąć udział dwaj kandydaci, którzy 
wzięli udział w pierwszej turze: ten, który zdobył największą liczbę głosów w całym państwie oraz jeden z pozostałych kandydatów (art. 134 [3] [a] i [b]). W Konstytucji przewidziano, że w tym drugim przypadku do drugiej tury wyborów prezydenckich przechodzi nie kandydat, który uzyskał drugą największą liczbę głosów w całym państwie, lecz ten, który zdobył największą liczbę głosów w największej liczbie stanów Nigerii ${ }^{10}$ (art. 134 [3] [b]). Postanowienie to wzmacnia znaczenie wymogu uzyskania terytorialnego rozłożenia głosów w wyborach prezydenckich w Nigerii.

Niemniej jednak, kontynuując wątek kandydata uprawnionego do przejścia do drugiej tury jako kandydata drugiego, w Konstytucji przewidziano również sytuację, w której dwaj kandydaci zdobywają wysoki wynik wyborczy w identycznej liczbie stanów, uprawniając wówczas do ponownego kandydowania tego z nich, który uzyskał najwyższą liczbę głosów w całym państwie (art. 134 [3] [b]).

Druga tura wyborów prezydenckich w Nigerii może, lecz nie musi wyłonić głowę państwa. Zgodnie z Konstytucją, aby jeden z kandydatów startujących w tej turze mógł objąć urząd prezydenta, oprócz zdobycia zwykłej większości głosów musi - tak jak w przypadku pierwszej tury - uzyskać nie mniej niż jedną czwartą głosów oddanych w każdym z co najmniej dwóch trzecich ogółu stanów federacji (liczonych wraz z FTS; art. 134 [4] [a] i [b]). Gdy żaden kandydat nie spełni przewidzianych wymogów, to wówczas NPKN powinna w przeciągu 7 dni od ogłoszenia wyników drugiej tury wyborów prezydenckich ustalić termin ich trzeciej tury.

W trzeciej turze wyborów prezydenckich w Nigerii biorą udział obaj kandydaci z drugiej tury wyborów. Prezydentem powinien zostać ten spośród nich, który zdobędzie w niej po prostu większość głosów (art. 134 [5]). Konstytucja Nigerii przewiduje zatem rezygnację z wymogu uzyskania terytorialnego rozłożenia głosów dopiero w trzeciej turze wyborów prezydenckich.

\section{Wcześniejsze rozwiązania nigeryjskie}

Nigeryjskie postanowienia dotyczące wymogu uzyskania terytorialnego rozłożenia głosów w wyborach prezydenckich zawarte w Konstytucji tzw. Czwartej Republiki z 1999 r. w większości kwestii są tożsame z rozwiązaniami zawartymi

${ }^{10}$ W tym przypadku w Konstytucji z 1999 r. nie wskazano, czy stany Nigerii są liczone wraz z FTS. 
w Konstytucji tzw. Drugiej Republiki z 1 października 1979 r., w której po raz pierwszy zastosowany został przedmiotowy wymóg (Benjamin, 2008) ${ }^{11}$.

Istnieje jednak zasadnicza różnica dotycząca postępowania w sytuacji, gdy głowa państwa nie zostałaby wybrana ani w pierwszej, ani w drugiej turze wyborów powszechnych ${ }^{12}$. Konstytucja z 1999 r. nakazuje w takim stanie rzeczy rozpisanie trzeciej tury powszechnych wyborów prezydenckich, w której nie wymaga się spełnienia przez zwycięskiego kandydata wymogu uzyskania terytorialnego rozłożenia głosów (art. 134 [5]). Natomiast Konstytucja z 1979 r. nie przewidywała rozpisania trzeciej tury wyborów. Zgodnie z jej postanowieniami (art. 126 [4]), gdyby kandydat, który w drugiej turze wyborów prezydenckich zdobył zwykłą większość głosów, nie spełnił wymogu uzyskania terytorialnego rozłożenia głosów, wówczas NPKN powinna w ciągu 7 dni od ogłoszenia wyników drugiej tury wyborów prezydenckich ustalić termin wyboru prezydenta spośród dwóch kandydatów, którzy konkurowali w drugiej turze wyborów. Wybór ten miałby jednak zostać dokonany przez członków obu izb federalnego Zgromadzenia Narodowego (House of the National Assembly) oraz parlamentu każdego ze stanów federacji (Zgromadzenia Stanowego, House of Assembly of a State). Jeden z dwóch kandydatów, który uzyskałby zwykłą większość głosów oddanych łącznie we wszystkich wskazanych ciałach legislacyjnych, objąłby urząd prezydenta. Postanowienia te nigdy nie zostały wypróbowane w praktyce. Można je jednak traktować w charakterze opcji możliwej do zastosowania w sytuacji braku rozstrzygnięcia wyborów głowy państwa w dwóch turach głosowania powszechnego.

11 Tzw. Druga Republika upadła wraz z wojskowym zamachem stanu w 1983 r. Późniejsza próba utworzenia tzw. Trzeciej Republiki Nigerii w 1993 r. zakończyła się niepowodzeniem. Konstytucja Trzeciej Republiki z 1993 r. nigdy nie weszła w pełni w życie, a wojsko utrzymało władzę w Nigerii w latach 1983-1999.

12 Ponadto, choć Konstytucja z 1979 r. wymagała sprostania przez zwycięskiego kandydata w wyborach prezydenckich tym samym wymaganiom, co Konstytucja z 1999 r., to pierwotnie odnosiły się one wyłącznie do stanów, a więc nie dotyczyły FTS (Abudży), mimo że zostało ono ustanowione w 1976 r. Należy to tłumaczyć faktem, że na początku swojego formalnego istnienia Abudża była zamieszkana przez niewielką liczbę osób, a proces przenoszenia do niej stolicy z Lagos trwał wiele lat i został oficjalnie zakończony dopiero w $1991 \mathrm{r}$. 


\section{Obecne rozwiązania kenijskie}

Zgodnie z Konstytucją Kenii z 27 sierpnia 2010 r. prezydent tego państwa jest głową państwa i stoi na czele gabinetu (art. 131 [1] [a] i [b]). Wybierany jest w wyborach powszechnych na okres pięciu lat (art. 136 [1] i [2] [a]). Ta sama osoba nie może pełnić urzędu prezydenckiego więcej niż przez dwie kadencje (art. 142 [2]). Kandydaci na prezydenta mogą zostać wyznaczeni przez partie polityczne lub ubiegać się o wybór jako kandydaci niezależni ${ }^{13}$, jednak w obu przypadkach muszą wpierw uzyskać nominację nie mniej niż 2 tys. wyborców w ponad połowie ogółu hrabstw (counties) (art. 137 [1] [c] i [d]).

Wymóg uzyskania terytorialnego rozłożenia głosów w wyborach prezydenckich w Kenii ma odniesienie do hrabstw jako podstawowych jednostek podziału terytorialnego. Jest ich 47, łącznie ze stołecznym Miastem Nairobi (art. 6 [1]).

Zgodnie z Konstytucją prezydentem Kenii zostaje kandydat, który zdobywa w wyborach więcej niż połowę wszystkich oddanych głosów oraz co najmniej 25\% głosów oddanych w więcej niż połowie ogółu hrabstw (art. 138 [4]). Wymóg uzyskania terytorialnego rozłożenia głosów przewidziany został jednak tylko dla pierwszej tury wyborów prezydenckich. W przypadku niespełnienia w niej obu wymienionych warunków przez żadnego z kandydatów, druga tura wyborów powinna odbyć się najpóźniej 30 dni po pierwszej, a udział w niej mogą wziąć dwaj kandydaci, którzy w pierwszej turze uzyskali najwięcej głosów (art. 138 [5]). Zdobywca największego poparcia w drugiej turze jest ogłaszany prezydentem bez konieczności uzyskania co najmniej $25 \%$ głosów w więcej niż połowie hrabstw (art. 138 [7]).

\section{Wcześniejsze rozwiązania kenijskie}

Wymóg uzyskania terytorialnego rozłożenia głosów zaczął funkcjonować w Kenii w 1992 r. (Bogaards, 2008), a zatem jeszcze pod rządami Konstytucji z 1969 r. ${ }^{14}$, do której w okresie wprowadzania w Kenii pluralizmu politycznego

13 Zgodnie z art. 2 Kenijskiego Kodeksu Wyborczego nr 24 z 2011 r. kandydat niezależny to taki, który nie jest członkiem żadnej partii. Zgodnie z art. 33 (a) tego Kodeksu kandydat niezależny nie może być członkiem jakiejkolwiek partii co najmniej na 3 miesiące poprzedzające datę wyborów prezydenckich.

${ }^{14}$ W literaturze przedmiotu mianem Konstytucji Kenii z 1969 r. (przyjętej jako Ustawa nr 5 z 10 kwietnia 1969 r.) nazywana jest wersja tzw. Konstytucji Niepodległościowej Kenii z 1 czerwca 1963 
dodane zostały - mocą Ustawy nr 12 z 1991 r. i Ustawy nr 6 z 1992 r. - poprawki zmieniające zasady wyboru głowy państwa. Postanowienia z 1992 r. dotyczące przedmiotowego wymogu istotnie jednak różniły się od obecnie obowiązujących. Prezydentem Kenii mógł bowiem już w pierwszej turze zostać kandydat, który był pochodzącym z wyboru członkiem Zgromadzenia Narodowego (obecnie takiego wymogu nie ma) i który zdobył w wyborach prezydenckich „większą liczbę ważnie oddanych głosów” niż „jakikolwiek inny kandydat” (obecnie musi to być więcej niż połowa ogółu oddanych głosów) oraz co najmniej $25 \%$ ważnie oddanych głosów „W co najmniej pięciu z ośmiu prowincji” (obecnie musi to być co najmniej 25\% głosów oddanych w więcej niż połowie ogółu hrabstw) (art. 5 [3] [f] Konstytucji z 1969 r.). Znowelizowana w latach 1991-1992 Konstytucja z 1969 r. miała zatem w stosunku do przepisów Konstytucji z 2010 r. łagodniejsze postanowienia dotyczące konieczności zdobycia przez faworyta wyborów prezydenckich przewagi, mierzonej liczbą głosów, nad innymi kandydatami (większość względna zamiast bezwzględnej) i surowsze rozwiązania odnoszące się do konieczność uzyskania ponad jednej czwartej głosów w podstawowych jednostkach podziału terytorialnego państwa (niemal dwie trzecie regionów versus ponad ich połowa).

\section{Rozwiązania indonezyjskie}

Konstytucja Republiki Indonezji z 18 sierpnia 1945 r. po wprowadzeniu poprawek: Trzeciej z 9 listopada 2001 r. i Czwartej z 11 sierpnia 2002 r. (Schneier, 2005; Ellis, 2005, Horowitz, 2013) przewiduje, że wybierany w wyborach powszechnych (art. 6A [1]) na pięcioletnią kadencję (art. 7) prezydent jest głową państwa i szefem rządu Indonezji (art. 4 [1] i art. 5). Ta sama osoba nie może pełnić urzędu prezydenckiego więcej niż dwukrotnie (art. 7). Kandydata na prezydenta może wysunąć albo partia polityczna, albo koalicja partii politycznych (art. 6A [2]).

Aby w pierwszej turze wygrać wybory prezydenckie w Indonezji, należy zdobyć nie tylko więcej niż 50\% głosów oddanych w całym państwie, ale jednocześnie co najmniej $20 \%$ głosów w więcej niż połowie jego prowincji

r., w której skonsolidowano wszystkie poprawki wprowadzone do ustawy zasadniczej w latach 1964-1969 (Rubin, Cotran, 2014). 
(art. 6A [3] $)^{15}$.W sytuacji, gdy żaden kandydat nie uzyskuje takiego poparcia, do drugiej tury wyborów przechodzą dwaj kandydaci na prezydenta, którzy w pierwszej turze zdobyli największą liczbę głosów. Ten z dwójki kandydatów, który w drugiej turze zdobędzie większą liczbę głosów, obejmuje urząd głowy państwa (art. 6A [4]).

\section{Zakończenie}

W tej części artykułu dzięki porównaniu konkretnych, konstytucyjnych postanowień dotyczących wymogu uzyskania terytorialnego rozłożenia głosów w wyborach prezydenckich w Nigerii, Kenii i Indonezji wskazane zostaną występujące między nimi obecnie różnice. Następnie podjęta zostanie próba odpowiedzi na pytanie, czy instytucja przedmiotowego wymogu wpływa na obniżenie znaczenia konfliktowych zachowań w relacjach między grupami etnicznymi oraz budowanie międzyetnicznej akomodacji w wymienionych państwach, a zatem czy spełnia cele, dla których została powołana i funkcjonuje.

\section{RÓŻNICE MIĘDZY TREŚCIĄ PRZEDMIOTOWEGO WYMOGU W PORZĄDKACH KONSTYTUCYJNYCH NIGERII, KENII I INDONEZJI}

Postanowienia konstytucji Nigerii, Kenii i Indonezji dotyczące wymogu uzyskania terytorialnego rozłożenia głosów w wyborach prezydenckich są pod wieloma względami odmienne. Po pierwsze, bardziej niż w przypadkach Kenii i Indonezji skomplikowane są zasady konstytuujące przedmiotowy wymóg w Nigerii, w której teoretycznie może dojść do trzech tur wyborów prezydenckich, przy czym aż w dwóch pierwszych turach funkcjonuje przedmiotowy wymóg. W Kenii i Indonezji może dojść do najwyżej dwóch tur wyborów głowy państwa, a wymóg ów musi zostać spełniony jedynie w pierwszej turze.

Po drugie, choć w każdym z trzech państw wymogowi uzyskania terytorialnego rozłożenia głosów w wyborach prezydenckich towarzyszy typowy dla wyborów na jednoosobowy urząd wymóg zdobycia większościowego poparcia,

${ }^{15}$ W 2014 r. ich liczba wynosiła 34. Jednak w izbie niższej indonezyjskiego parlamentu toczą się dyskusje na temat utworzenia do 2025 r. aż 11 kolejnych prowincji (Max, 2012). 
to w przypadku Nigerii jest to wymóg uzyskania względnej większości głosów, podczas gdy w przypadkach Kenii i Indonezji - większości bezwzględnej.

Po trzecie, w każdym z trzech państw zostały ustalone nieco odmienne zasady dotyczące procentowo określonego poziomu poparcia, jaki zwycięski kandydat musi uzyskać w podstawowych jednostkach podziału terytorialnego państwa (stanach, hrabstwach lub prowincji) oraz ich liczby. I tak w przypadku Nigerii poziom ten wynosi minimum $25 \%$ głosów oddanych w każdym z co najmniej $2 / 3$ wszystkich stanów federacji, liczonych wraz z FTS (w 2015 r. samych stanów było 36). Postanowienia te stosowane są w Nigerii do pierwszej i - w razie potrzeby - do drugiej tury wyborów prezydenckich. W przypadku Kenii jest to minimum 25\% głosów oddanych w ponad połowie ogółu hrabstw (ich liczba w 2015 r. wynosiła 47). Jeszcze inny jest przypadek Indonezji, gdzie poziom ten został określony na minimum $20 \%$ głosów oddanych w więcej niż połowie prowincji (w 2015 r. było ich 34).

\section{CZY INSTYTUCJA PRZEDMIOTOWEGO WYMOGU SPEŁNIA CELE, DLA KTÓRYCH ZOSTAŁA POWOŁANA?}

Instytucja wymogu uzyskania terytorialnego rozłożenia głosów w wyborach prezydenckich odstaje od typowych rozwiązań istniejących w liberalnej demokracji większościowej. W tym przeważającym obecnie modelu demokracji nie może bowiem dojść do sytuacji, w której arytmetycznemu zwycięzcy wyborów prezydenckich, a zatem takiemu, który zdobył większość głosów wyborców (w zależności od prawnych wymogów: bezwzględną lub względną), nie jest dane objęcie urzędu, gdyż uzyskane przezeń poparcie nie przybrało odpowiedniego, terytorialnego rozłożenia w określonej, większościowej części regionów danego państwa. Bynajmniej nie znaczy to, że przedmiotowa instytucja nie jest demokratyczna.

Niemniej jednak faktem jest, że spośród trzech państw, w których funkcjonuje przedmiotowy wymóg, jedynie w Indonezji funkcjonuje reżim demokratyczny. Wszystkie opublikowane dotychczas przez uznany ośrodek badawczy The Economist Intelligence Unit (2015) raporty dotyczące stanu demokracji w świecie wskazują, że na początku XXI wieku spośród trzech państw, w których istnieje wymóg uzyskania terytorialnego rozłożenia głosów w wyborach prezydenckich, jedynie Indonezja uznawana jest - zgodnie z przyjętymi przez twórców raportów rozbudowanymi kryteriami - za państwo demokratyczne, a konkretnie za 
państwo posiadające niedoskonały (flawed) reżim demokratyczny. Podobnie Horowitz (2013, s. 207) określa Indonezję mianem „demokracji o niskiej jakości” (low-quality democracy), gdyż - jak to ujmuje - w państwie tym nadal istnieją obszary „opóźnionego rozwoju” (delayed development) (Horowitz, 2013, s. 209). Za najważniejsze z nich Horowitz uznaje cztery: szczególny status armii (mającej nadal wpływ na życie polityczne oraz często nieponoszącej konsekwencji nieprzestrzegania prawa), nadmiar korupcji, deficyt rządów prawa i wysoki stopień nietolerancji religijnej.

Odnośnie pozostałych dwóch państw, w których funkcjonuje przedmiotowy wymóg, od początku publikowania raportów pt. Democracy Index we wszystkich ich edycjach Nigeria uznawana jest za państwo autorytarne, a Kenia - sytuowana wśród państw mających reżim hybrydowy. Jest to o tyle ważny fakt, że demokratyczny charakter wyborów prezydenckich przeprowadzanych w Nigerii i Kenii jest wątpliwy, podobnie jak i ich wyniki.

Dość powiedzieć, że nigdy w żadnym z państw, w których funkcjonuje przedmiotowy wymóg, nie doszło do sytuacji, w której faworyt w wyścigu wyborczym do fotela prezydenckiego nie objąłby urzędu z powodu niespełnienia wymogu uzyskania terytorialnego rozłożenia głosów w wyborach prezydenckich. I tak, w Nigerii pod rządami Konstytucji z 1999 r. wybory prezydenckie odbyły się w latach: 2003, 2007, 2011 i 2015. Zgodnie z oficjalnymi wynikami każdorazowo jeden $\mathrm{z}$ kandydatów wygrał w pierwszej turze i zawsze zdobywał ponad 50\% oddanych głosów, pomimo faktu, iż w państwie tym, przy sprostaniu wymogowi terytorialnego rozłożenia głosów, wybory może wygrać kandydat, który zdobył po prostu największą liczbę głosów, a zatem uzyskał większość względną (African Elections Database, 2003, 2007b, 2011).

Pod rządami Konstytucji z 1979 r., w latach 1979-1999, wybory prezydenckie odbywały się czterokrotnie. W 1979 r. i 1983 r. faworyt wyborów wygrał je w pierwszej turze, uzyskując względną większość głosów (African Elections Database, 1979, 1983), zaś w 1993 r. i 1999 r. faworyt wyborów również wygrał je w pierwszej turze, uzyskując jednak bezwzględną większość głosów (African Elections Database, 1993,1999).

Z kolei w Kenii, w zgodzie z postanowieniami znowelizowanej w latach 1991-1992 Konstytucji z 1969 r., zawierającej wymóg terytorialnego rozłożenia głosów, przeprowadzono wybory prezydenckie w latach: 1992, 1997, 2002 i 2007. Według oficjalnych wyników każdorazowo kandydat wybrany na prezydenta spełnił w pierwszej turze wymogi stawiane zwycięzcy przez ustawę zasadniczą (African Elections Database, 1992, 1997, 2002, 2007a). Z kolei na podstawie Kon- 
stytucji Kenii z 2010 r. dotychczas dokonano w tym państwie wyboru prezydenta raz, w 2013 r. Wybory te miały jedną turę, w której faworyt wyborów spełnić miał oba wymogi, zdobywając ponad połowę ogółu oddanych głosów i co najmniej 25\% głosów w więcej niż połowie ogółu hrabstw (GeoCurrents, 2013).

Tylko nieco inaczej wygląda sytuacja w niedoskonałej demokracji indonezyjskiej. Po wprowadzeniu w latach 2001-2002 Poprawek: Trzeciej i Czwartej do Konstytucji z 1945 r. wybór prezydenta Indonezji odbył się w głosowaniu powszechnym już trzykrotnie, w latach: 2004, 2009 i 2014 (Carter Center, 2005; Ufen, 2010; International Foundation for Electoral Systems, 2014). Jedynie wybory z 2004 r. miały dwie rundy, co wiązało się jednak z faktem, że ich faworyt nie otrzymał w pierwszej turze wymaganej ponad połowy oddanych w całym państwie głosów.

Przytoczone dane nie świadczą o tym, że przedmiotowy wymóg pozbawiony jest w praktyce znaczenia. Przeciwnie, mogą one sugerować, że zwycięzcy wyborów są politykami, których poglądy i działania, zwłaszcza w kwestiach drażliwych dla międzyetnicznych relacji, mają charakter powściągliwy. Umiar w polityce pozwala im zaś na uzyskanie poparcia szerszego niż tylko grupy etnicznej, z której się wywodzą. Ponieważ jednak w Nigerii, Kenii i Indonezji funkcjonują systemy prezydenckie, których nieodłączną częścią jest instytucja wiceprezydenta, można równie dobrze wnioskować, że na przykład dobranie w wyborach prezydenckich przez kandydata na głowę państwa partnera na urząd wiceprezydenta o odmiennym pochodzeniu etnicznym, również może wpływać pozytywnie na wynik wyborczy ${ }^{16}$.

Ponieważ jak dotąd, ze względu na deficyt lub niską jakość demokracji, brakuje przekonujących, wiarygodnych dowodów, że instytucja wymogu uzyskania terytorialnego rozłożenia głosów w wyborach prezydenckich wpływa na obniżenie znaczenia konfliktowych zachowań w relacjach między grupami etnicznymi i budowanie międzyetnicznej akomodacji w wymienionych państwach, pozostaje jedynie wierzyć, że tak w rzeczy samej jest. Choć, co prawda, natężenie konfliktów etnicznych w Nigerii i Indonezji wydaje się być w XXI wieku mniejsze niż w wieku $\mathrm{XX}^{17}$, to prawidłowości tej nie sposób bezpośrednio przypisać jedynie zastosowaniu w tych państwach przedmiotowej instytucji. Na obniżenie znaczenia konfliktowych zachowań w relacjach między grupami etnicznymi i budowanie międzyetnicznej akomodacji może równie dobrze wpływać wiele

\footnotetext{
16 Świadczy o tym choćby przykład Kenii (African Studies Center Leiden, 2013).

17 Jak już wcześniej zostało zauważone, odwrotna sytuacja ma jednak miejsce w Kenii.
} 
innych czynników, w tym istnienie rozmaitych instytucji służących osłabianiu znaczenia podziałów etnicznych w warunkach wieloetniczności. Można mieć jednak nadzieję, że rację ma Horowitz, gdy wskazuje, że wymóg uzyskania terytorialnego rozłożenia głosów w wyborach prezydenckich jest przykładem rozwiązania sprzyjającego mniej konfliktowym zachowaniom we wzajemnych relacjach reprezentowanych przez polityków grup etnicznych $\mathrm{w}$ warunkach społeczeństw głęboko podzielonych, zwłaszcza jeśli instytucji tej towarzyszą inne rozwiązania mające za cel osiągnięcie tożsamego efektu.

\section{BiBLIOGRAFIA:}

African Elections Database. (1979). Elections in Nigeria: 11 August 1979 Presidential Election. Pobrane z: http://africanelections.tripod.com/ng.html\#1979_Presidential_Election.

African Elections Database. (1983). Elections in Nigeria: 6 August 1983 Presidential Election. Pobrane z: http://africanelections.tripod.com/ng.html\#1983_Presidential_Election.

African Elections Database. (1992). Elections in Kenya: 29 December 1992 Presidential Election. Pobrane z: http://africanelections.tripod.com/ke.html\#1992_Presidential_Election.

African Elections Database. (1993). Elections in Nigeria: 12 June 1993 Presidential Election. Pobrane z: http://africanelections.tripod.com/ng.html\#1993_Presidential_Election.

African Elections Database. (1997). Elections in Kenya: 29 December 1997 Presidential Election. Pobrane z: http://africanelections.tripod.com/ke.html\#1997_Presidential_Election.

African Elections Database. (1999). Elections in Nigeria: 27 February 1999 Presidential Election. Pobrane z: http://africanelections.tripod.com/ng.html\#1999_Presidential_Election.

African Elections Database. (2002). Elections in Kenya: 27 December 2002 Presidential Election. Pobrane z: http://africanelections.tripod.com/ke.html\#2002_Presidential_Election.

African Elections Database. (2003). Elections in Nigeria: 19 April 2003 Presidential Election. Pobrane z: http://africanelections.tripod.com/ng.html\#2003_Presidential_Election.

African Elections Database. (2007a). Elections in Kenya: 27 December 2007 Presidential Election. Pobrane z: http://africanelections.tripod.com/ke.html\#2007_Presidential_Election.

African Elections Database. (2007b). Elections in Nigeria: 21 April 2007 Presidential Election. Pobrane z: http://africanelections.tripod.com/ng.html\#2007_Presidential_Election. 
African Elections Database. (2011). Elections in Nigeria: 16 April 2011 Presidential Election. Pobrane z: http://africanelections.tripod.com/ng.html\#2011_Presidential_Election.

African Studies Center Leiden. (2013). The Results of the 2013 Kenyan Presidential Election. Pobrane z: http://www.ascleiden.nl/news/results-2013-kenyan-presidential-election.

Benjamin, R. (2008). Introduction. W: R. Benjamin, P. Nordlund (red.) Political Parties in Conflict-prone Societies: Regulation, Engineering, and Democratic Development, (s. 3-24). Tokyo-New York-Paris: United Nations University Press.

Bogaards, M. (2008). Comparative strategies of political party regulations. W: R. Benjamin, P. Nordlund (red.), Political Parties in Conflict-prone Societies: Regulation, Engineering, and Democratic Development, (s. 48-66). Tokyo-New York-Paris: United Nations University Press.

Carter Center. (2005). The Carter Center 2004 Indonesia Election Report. Pobrane z: http://www.cartercenter.org/documents/2161.pdf.

East Africa Living Encyclopedia. (2015). Kenya: Ethnic Groups. Pobrane z: http://www. africa.upenn.edu/NEH/kethnic.htm.

Economist Intelligence Unit. (2015). Democracy Indices: 2006, 2008, 2010-2014. Pobrane z: http://www.eiu.com/Exception.aspx?aspxerrorpath=/public/topical_report.aspx

Ellis, A. (2005). Constitutional Reform in Indonesia: A Retrospective. Pobrane z: http:// www.constitutionnet.org/files/AEpaperCBPIndonesia.pdf.

Encyclopedia of the Nations. (2015a). Kenya: Ethnic Groups. Pobrane z: http://www. nationsencyclopedia.com/Africa/Kenya-ETHNIC-GROUPS.html.

Encyclopedia of the Nations. (2015b). Nigeria. Pobrane z: http://www.nationsencyclopedia.com/economies/Africa/Nigeria.html.

Ethnologue - Languages of the World. (2015a). Kenya. Pobrane z: http://www.ethnologue.com/country/KE.

Ethnologue - Languages of the World. (2015b). Nigeria. Pobrane z: http://www.ethnologue.com/country/NG.

GeoCurrents. (2013). Intense Ethnic Divisions in the 2013 Kenyan Election. Pobrane z: http://www.geocurrents.info/geonotes/intense-ethnic-divisions-in-the-2013kenyan-election\#ixzz3UUiPxffB.

Geohive. (2015). Current World Population. Pobrane z: http://www.geohive.com/earth/ population_now.aspx.

Henderson, E.A. (1999). Ethnic Conflict and Cooperation. W: L. Kurtz (red.), Encyclopedia of Violence, Peace, and Conflict, 1, (s. 751-765). San Diego: Academic Press.

Horowitz, D.L. (1985). Ethnic Groups in Conflict. Berkeley, CA: University of California Press.

Horowitz, D.L. (2013). Constitutional Change and Democracy in Indonesia. New York: Cambridge University Press.

Horowitz, D.L. (2014). Ethnic power sharing: Three big problems. Journal of Democracy, 25(2), s. 5-20. 
Index Mundi. (2014a). Indonesia Demographics Profile 2014. Pobrane z: http://www. indexmundi.com/indonesia/demographics_profile.html.

Index Mundi. (2014b). Kenya Demographics Profile 2014. Pobrane z: http://www. indexmundi.com/kenya/demographics_profile.html.

Index Mundi. (2014c). Nigeria Demographics Profile 2014. Pobrane z: http://www. indexmundi.com/nigeria/demographics_profile.html.

International Foundation for Electoral Systems. (2014). Final Results of the 2014 Presidential Election in Indonesia Announced. Pobrane z: http://www.ifes.org/Content/ Publications/News-in-Brief/2014/July/Final-Results-of-the-2014-PresidentialElection-in-Indonesia-Announced.aspx.

Kaufman, S.J. (2011). Ethnicity as a Generator of Conflict. W: K. Cordell, S. Wolff (red.), Routledge Handbook of Ethnic Conflict, (s. 91-102). London: Routledge.

Kenijski Kodeks Wyborczy nr 24 z 2011 r. (2012). Pobrane z: http://www.parliament. go.ke/plone/statutory-documents/elections-act-no.-24-of-2011-revised-edition-2012.

Konstytucja Kenii z 27 sierpnia 2010 r. (2010). Pobrane z: http://www.kenyalaw.org/kl/ fileadmin/pdfdownloads/Constitution_of_Kenya_2010.pdf.

Konstytucja Republiki Federalnej Nigerii z 1 października 1979 r. (uchwalona 21 września 1978 r.). (1979). Pobrane z: http://www.constitutionnet.org/files/nig_const_79. pdf.

Konstytucja Republiki Federalnej Nigerii z 29 maja 1999 r. (1999). Pobrane z: http:// www.wipo.int/wipolex/en/text.jsp?file_id=179202.

Konstytucja Republiki Indonezji z 18 sierpnia 1945 r. (z późniejszymi poprawkami). (1945). Pobrane z: http://www.wipo.int/edocs/lexdocs/laws/en/id/id061en.pdf.

Lijphart, A. (1995). Multiethnic democracy. W: S.M. Lipset (red.), The Encyclopedia of Democracy, 3, (s. 853-865). London: Routledge.

Macdonald, G. (2013). Election Rules and Identity Politics: Understanding the Success of Multiethnic Parties in Indonesia. Pobrane z: http://www.ifes.org/ /media/Files/ Publications/White\%20PaperReport/2013/2012_Hybl_Fellowship_Final.pdf.

Max, S.R. (2012). How Many Provinces Does Indonesia Need?. Pobrane z: http://www. thejakartapost.com/news/2012/04/20/how-many-provinces-does-indonesia-need. html.

McGibbon, R. (2004). Secessionist Challenges in Aceh and Papua: Is Special Autonomy the Solution? Washington, DC: East-West Center Washington.

Obi-Ani P.O. (2005). Nigeria: Biafran Secession and Civil War, 1967-1970. W: K. Shillington (red.). Encyclopedia of African History, 2, (s. 1114-1115). New York-London: Fitzroy Dearborn.

Rubin, N.N., Cotran, E. (red.). (2014). Annual Survey of African Law 1969, 3. New York: Routledge.

Schneier, E. (2005). The Role of Constitution-building Processes in Democratization: Case Study - Indonesia: The Constitution-building Process in Post-Suharto Indonesia. Pobrane z: http://www.idea.int/cbp/upload/CBP_indonesia.pdf. 
Sisk, T.D. (1996). Power Sharing and International Mediation in Ethnic Conflicts. Washington, DC: United States Institute of Peace.

Suberu, R. (2006). Federalism and the Management of Ethnic Conflict: The Nigerian Experience. W: D. Turton (red.). Ethnic Federalism: The Ethiopian Experience in Comparative Perspective (s. 65-92). Oxford: James Currey.

Szupejko, M. (2012). Negatywna etniczność a zmiany konstytucyjne w Kenii 2010 roku. Afryka, 36, s. 24-37.

Ufen, A. (2010). The Legislative and Presidential Elections in Indonesia in 2009. Electoral Studies: An International Journal, 29(2), s. 281-285. 